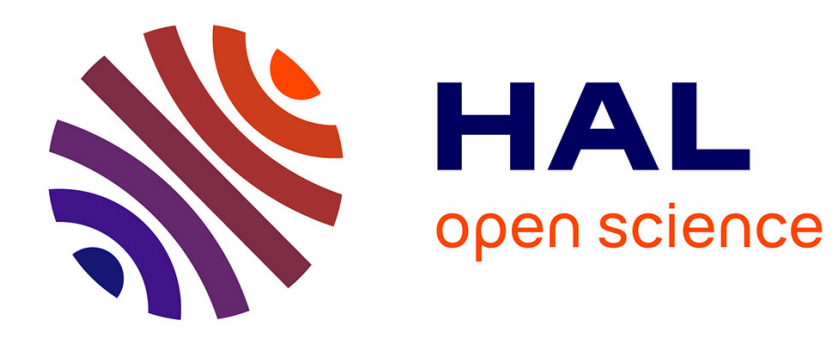

\title{
Dutch documentary film as a site of memory
}

Sonja de Leeuw

\section{To cite this version:}

Sonja de Leeuw. Dutch documentary film as a site of memory. European Journal of Cultural Studies, 2007, 10 (1), pp.75-87. 10.1177/1367549407072971 . hal-00571535

\section{HAL Id: hal-00571535 \\ https://hal.science/hal-00571535}

Submitted on 1 Mar 2011

HAL is a multi-disciplinary open access archive for the deposit and dissemination of scientific research documents, whether they are published or not. The documents may come from teaching and research institutions in France or abroad, or from public or private research centers.
L'archive ouverte pluridisciplinaire $\mathbf{H A L}$, est destinée au dépôt et à la diffusion de documents scientifiques de niveau recherche, publiés ou non, émanant des établissements d'enseignement et de recherche français ou étrangers, des laboratoires publics ou privés. 
Copyright (C) 2007 SAGE Publications London, Los Angeles, New Delhi and Singapore Vol 10 (1) $75-87 ; 1367-5494$ DOI: $10.1177 / 1367549407072971$ WWW.sagepublications.com

\section{Dutch documentary film as a site of memory Changing perspectives in the 1990 s}

\section{Sonja de Leeuw}

University of Utrecht

ABSTRACT This article discusses how documentary film as site of memory has constructed the memory of the Second World War. Its focus is on Dutch documentary films produced by the end of the 1980s and in the 1990s and their relation to both the discourses of memory and of documentary representation. The construction of memory is closely related to the debate on historical representation, centred around the Shoah as an event of extreme importance. This article addresses these debates as well as the interventions made by filmmakers. With the help of several examples from Dutch documentary practice, its aim is to illustrate how representational modes in documentary film are related to the construction of memory.

KEYWORDS documentary, memory, representation, Shoah, The Netherlands

Documentary filmmakers dealing with historical events can be regarded as historiographers in the sense that they reconstruct and recreate history. By offering visualized comments and reflections, they intervene in the debate about historiography and historical representation. There is a line running from Alain Resnais' Night and Fog (1955) to the work of Marcel Ophüls ${ }^{1}$ and to Claude Lanzmann's epic work Shoah (1985). In referring to the Shoah, all deal with the question of how to represent the 'unknown' and the unspeakable while trying to offer documentary ways of remembering a historical event as immeasurable as the Shoah. Documentary films thus create sites for remembering, by rewriting history through representations. As Young (1988: 1) puts it, "what is remembered of the Holocaust depends on how it is remembered and how its events are remembered depends in turn on the texts now giving them form'. These various texts, which include monuments, literature, diaries and films, are diverse and incomparable commemoration practices as they are positioned differently in the public domain and also in (popular) culture.

By the end of the 1980 s there was a renewed interest in telling stories about the past and the Shoah in particular. This seems even more true for 
filmmakers, who often try and fill the gaps in historiography by focusing on history from below (using ordinary people as witnesses) as a confrontation with official history. Alternatively, they discuss historiography as such by using cinematic devices to reveal history as representation.

This article discusses how documentary film as a site of memory has constructed the memory of the Shoah. Its focus is on Dutch documentary films produced by the end of the 1980s and in the 1990s. Several debates have informed the choice of films and these will be addressed further later on. First, documentary film embodies the core of the debate on (historical) representation because of its evident relation with 'reality'. Second, for several reasons the Shoah questions representational strategies in general, and historical representation in particular. Finally, there is a case to make for Dutch documentary film, as it has received acclaim and worldwide approval since the 1950s.

The 1950 s, known as the post-war reconstruction era, produced a large quantity of mainly short documentaries, many of which received first prizes at international film festivals. Immediately after the Second World War, documentary film in The Netherlands was recognized as an art form which should be supported by the government. The financing, through orders from government and business, did not prevent documentary filmmakers from developing an artistic, even lyrical, style as cinematographers. Moreover, the solid basis of commissioned films made it possible to develop independent productions, and the so-called 'Dutch School' was born. After a period of decline in the 1960s and 1970s, due to the prioritization of market forces over artistic expression in the film industry (which affected documentary film in particular as it does not usually attract a large cinema audience), documentaries disappeared almost totally from the cinema. In addition, public broadcasting companies were competing for the best ratings and therefore preferred cheap current affairs programmes and information. Documentary departments were closed; the consequence was that independent creative documentaries could rarely be seen on TV. In the 1980 s, filmmakers slowly recovered lost ground, and this was reinforced by the arrival of both the International Documentary Film Festival in Amsterdam, and the foundation of the Dutch Cultural Broadcasting Promotion Fund (which subsidizes cultural broadcasting productions) in 1988. This made room for individual and creative documentary production, and for the articulation of a renewed interest in national history, among which the Shoah stands out as having shaped collective memory. Television, again, became the most important commissioner, presenting a distribution forum for authored documentary productions.

Three documentaries have been selected in order to demonstrate how these authored voices demonstrate a way to deal with the issues involved in representing the Shoah. Not all of them deal exclusively with the Shoah, but they each address the commemoration of the Shoah as well as 
collective memory and its evolution over time. All three films deal with a subject that has gained iconic meaning, in the sense that its historical and individual specificity was effaced to become an abstraction. It is not the aim of this article to offer detailed textual analyses, although its observations are based upon close readings of the films. Rather, it focuses on the function of Dutch documentary in reshaping collective memory, and for that purpose it will refer to the narrative strategies of each of the films, and to some of their cinematic devices. It suggests that in the $1980 \mathrm{~s}$ and 1990s, Dutch documentary films no longer offered a depersonalized institutional discourse of memory, but had become various personalized individual discourses, both of the filmmakers themselves who tell their own story, and the story of the people whose voices they use. By sharing memories, documentary films present themselves as (almost) political tools, keeping alive social collective memory.

\section{Documentary and memory}

For the purpose of this article, the term 'memory' will be used in a broad sense. Jay Winter and Emmanuel Sivan $(1999)^{2}$ have pointed to 'memory' as a problematic concept, since it refers to individual (private) memories and collective (public) memories at the same time, as well as to articulated and non-articulated acts of memory. What is important here is that memory cannot be divided reasonably into sections that are psychologically or sociologically defined; rather, it transcends and crosses these domains where the psychological and the social act upon each other mutually. Memory is individually and socially constructed, its character is dynamic and therefore changeable.

How memory is constructed is discussed by the historian Saul Friedländer, who contributed fundamentally to the debate on representing the Shoah. His writings about deep (personal) and common memory are especially relevant here (Friedländer, 1993, 1994). In brief, he argues that there should be room for memory (deep and common memory). Deep memory is personal and causes loss of the coherent self on an individual level, while common memory, which is public and based on the backgrounds of the Shoah ('normal' pre- and post-camp routines), re-establishes coherency. Following Friedländer's argument, films can contribute to this process by integrating personal confrontation and the construction of public memory, showing emotion as well as distance.

The construction of memory is related closely to the debate on historical representation, centred around the Shoah as an event of extreme importance. Acknowledging that historical reality exists nowhere else but in its representation, the interconnection between representation and memory is evident (see Young, 1988). Documentary film takes on a specific position here due to its supposed relation to reality. 
Since the British documentary filmmaker and producer John Grierson described documentary in the late 1920 s as 'a creative treatment of actuality' (quoted in Winston, 1995: 11), the truth claim persistently turns up as one of the dominant characteristics of documentary film. Grierson's definition was contradictory, since his purpose was educational in the sense that he wanted to teach people about the world, for example, with the help of an institutional impersonal discourse ('the Voice of God'). At the same time, however, he made room for subjectivity in documentary filmmaking (his argument for 'creativity'), which may call upon the filmmaker's authored voice. As Nichols (1991) and Winston (1995) have argued, this is a very inaccurate definition of documentary, since it presupposes the reproduction of reality on the screen due to the power of photographic evidence: 'the camera never lies'. According to Winston,

the camera can, and inevitably must lie... The only compromise possible is to acknowledge the photographer so that the relation of image to imaged [i.e. mediated reality] depends not on the image's intrinsic quality guaranteed by science but on our reception of it as an image of the real guaranteed by (or corresponding to) our experience. (1995: 253)

As a consequence, documentary film should be detached from what Nichols has described as the 'discourses of sobriety' (1991: 29) (the context and realm of science and education to which it was attached), for the purpose of documentary practice that is subjective in its construction of reality and history as articulated in the use of narrative and cinematic means. Along this line of argument, the truth claim in documentary film refers to the degree of articulation of the filmmaker's view of reality, represented in the form and style of the film. From this viewpoint, the speaking position of the film (literally the voice through which the filmmaker speaks) is a very important stylistic principle. For this reason, we will pay attention to the voices that are used in the documentary films to be discussed below, and to how these help to shape and reshape the memory of the Shoah.

\section{Representational strategies}

Traditionally, documentary film is looked upon as a medium of (historical) documentary representation with a specific argumentative power, for a relatively large audience, using images as visual evidence. Realistic documentaries do not reveal the representation as representation; they present facts, images and witnesses as unproblematic. Realistic documentaries follow the concept of didacticism based on assumptions of truth (the Griersonian approach). It is a window-on-the-world approach based on the distinction between history and fiction, between fact and fiction. Responding to the question of how historical reality can be represented, traditionally realistic documentaries use audiovisual archival material as evidence of an authentic sign of their times, as well as a closed master narrative which explains the events. 
In representing the Shoah, the realist documentary tradition faces some difficulties. ${ }^{3}$ First, because of the lack of archival footage of the genocide itself, archival material cannot be used as argumentative evidence. There is some material, and now and then archival footage of the genocide is discovered to exist, but there is not much. Second, the resistance to any final narrativization in the form of a closed story runs counter to the realist discourse. Resistance against a 'final solution', so to speak, because the question of 'why' (i.e. 'why did this all happen?') cannot be answered.

Documentary filmmakers have developed diverse representational strategies to deal with the limits posed by the specific historical character of the Shoah, recounting the past with their own rules. ${ }^{4}$ They have used the realistic mode of representation in specific ways, as we will see. Besides, other representational techniques can be observed in recent documentary filmmaking, derived from modernism and postmodernism, which seem to run parallel to the challenges posed by the impossibility of capturing the Shoah experience in images. ${ }^{5}$ Hayden White (1996) argues that modernist anti-narration techniques, such as fragmentation, exploding the conventions of the traditional tale and splitting narrative functions, are the most appropriate techniques to represent the historical reality of our time with its 'unnatural' (unprecedented) catastrophes (see also Burgoyne, 1996).

If we extend this argument to the domain of documentary, we can argue that realistic storytelling, with its explanatory master narrative, presumes a narrative omniscience regarding the events which, precisely because of their size and range, elude total explanation. Modernist conventions offer the possibility of representing the traumatic events of the 20 th century in a manner that does not pretend to contain, define or control them. In her plea for postmodern fiction as a method for representing history, Staiger (1996) follows Linda Hutcheon in suggesting that postmodern fiction does not disconnect itself from history, but asks readers to question the process by which we represent ourselves and the world and to become aware of the means by which we make sense of experiences in our culture. With regard to documentary, the postmodernist approach might sound familiar to what has been described previously as an articulation of the construction of the represented reality. However, postmodernism restricts itself to an endless discussion with the past, in which looking for the truth (any truth) is no longer an aim. According to Hayden White (1996), everything is presented in postmodernist works as if it were of the same ontological order, both real and imaginary. As a result of this, the referential function of the images of the events fades, turns pale, as does the historical context of their production.

Since it has been argued here that because documentary filmmakers participate in discourses that offer reconstructions of social reality, and they have to account for the form and content of these reconstructions, a strict postmodernist approach does not seem to be appropriate at all. 
In discussing the relationship between history and postmodern theory, Robert Rosenstone (1996) also criticizes a postmodern approach which, in his view, is anti-history, because it problematizes the entire notion of historical knowled ge. He discusses ways to talk about and make meaning of the past, ways of encountering and experiencing past events instead of describing and analysing them. Referring to Hayden White, who suggested a new 'voice' in this context, Rosenstone suggests a so-called 'intransitive middle voice' (1996: 203), which lies somewhere between the objective voice of scholarship and the subjective voice of fiction and poetry. For him, by adding a visual component such a voice is precisely that of filmmakers, who attempt 'to forge a more meaningful relationship with the past' (1996: 216). This is true for documentary filmmakers in a specific way. According to Kaes (1989), it is the filmmaker who can translate all unrecorded and undocumented experiences of victims into pre-verbal images and thereby trigger the memories, associations and emotions necessary to historical writing.

\section{Documentary representational strategies}

In analysing documentary practice in the 1980 s and 1990 s, several developments can be observed. ${ }^{6}$ Documentary filmmaking (both inside and outside television) in the late 1980s and 1990s went beyond an integral audiovisual historiography of the Shoah as a cruel part of the occupation and destruction of The Netherlands, which had been the position taken by television during the 1960 s and early 1970s. It articulated a need for information and the reconstruction of what happened on a more formal and official level (i.e. history from above). Here, realistic representations dominate: the overall situation was represented and personal voices were only used to complete 'big history'. In the 1970 s, official history was questioned by moral discussions and modernist representations appeared. In the 1980 s, documentaries increasingly showed a shift towards case studies identifying previously unrecognized aspects of the historiography of the Shoah, which sustained dominant discourses of memory (of survivors, resistance fighters, etc.), following again a more or less realist representational strategy. Here, personal voices were integrated into a dominant 'national' voice, presented as the 'truth'. Exceptionally, a critical point of view can be observed, re-evaluating the Dutch wartime experience and demythologizing the common representation of a brave attitude during the war, while presenting a new 'truth' (see Vos, 1995) using modernist and postmodernist modes of representation, undercutting the truth claim.

In documentaries produced in the 1990 s modernism dominated, not always in the strictest sense, but in the sense of undercutting the truth claim, making more room for details and diversity of experiences, such as those of the second generation; sons and daughters who had begun to look for continuities and ruptures in their personal histories. The 
official reconstruction of historical events has left many gaps, such as the experiences of war children and women. The recollection of these, as well as of personal histories, became an important part of documentary filmmaking by the end of the 1980s and in the 1990s. These tendencies run parallel to Second World War historiography in The Netherlands, of which the recounting of the Shoah is a defining element. In documentary film, however, a public and private way of remembering have become integrated. The use of testimonies and the role of witnesses became crucial in reshaping collective memory. It is suggested that by articulating its position outside the "discourses of sobriety", documentary filmmaking has taken the opportunity to present individual stories as representations of memory and thus to provide a variety of discourses of memory, a variety of truths. And it has done so since the end of the 1980 s.

To elaborate further upon the changing relationship between documentary film as a site of memory, and questions of historical representation, this article will now turn to the three documentaries from the past 10 years which are most helpful in illustrating the reshaping of memory in The Netherlands. Although different in their representational modes, they deal with specific historical subjects and moments which have become indelible images, iconic images and iconic moments meant to remain permanent outside their specific historical context. First, we refer here to Anne Frank; second, to the seven-second film of the girl in the doorway of the train truck (the girl with the white headscarf); and finally to 4. May, Memorial Day. As part of our history, all of these have become of great significance for the Dutch commemoration of the Shoah.

\section{Three case studies}

First, an example of a documentary film which, in its representational mode, is still indebted to the realistic tradition of storytelling: Willy Lindwer's The Last Seven Months of Anne Frank (1989), made by a filmmaker specializing in Shoah stories that represent personal experiences. Almost exclusively based on oral history (the testimonies of women who lived beside Anne Frank during her last seven months), the film offers a universal story which does not follow the Anne Frank hype, but pays tribute to all female victims and survivors, and at the same time expresses the absurd horror of the Shoah.

The film deals with the very last transport from Westerbork (the Dutch transit camp for Auschwitz) to Auschwitz, on which Anne Frank travelled (3 September 1944). It is the first time that these women have told their story. The filmmaker meets with them individually to demonstrate that behind Anne Frank the symbol, there is Anne Frank the person; moreover, that there are other people as well. The power of the film comes from the women's recollections. We see them testifying within the familiar context of their homes (safe homes). By recounting in detail what has 
happened, these women are no longer objectified, as they were during their imprisonment, but become subjects again, women again, in front of the camera. The women each tell a part of the story which becomes a narrative (edited by the filmmaker) of destruction and survival.

This film does not reveal the act of representation. In this sense it presents a realistic discourse; facts, images and testimonies are presented as unquestioned. However, there is no doubt that these stories are private, belonging only to the women who tell them. Together they make up a story based on private ways of remembering which can function as a counterpart to the official history of camp routines. In the way that the testimonies are edited and in their interrelationship, the women's personal memories are elevated to a higher level which offers the viewers a more general framework of remembering the Shoah. The individual stories told by the women are edited so that together they form a narrative recalling what has happened from beginning to end. Also, in the editing, each individual's story contextualizes the 'symbolic' knowledge of Anne Frank, and as a consequence she is repositioned as one among the other girls who were murdered. The diversity of stories edited into one narrative enables a rereading of Anne Frank and of the Shoah, based upon recorded first-hand witness accounts.

The documentary film The Last Seven Month of Anne Frank contributes to what Friedländer describes as an integrative form of memory, where deep personal memory is given a place in the more or less normal life before and after the camp: integrating personal experiences and rational historiography (public memory), showing emotion (in the stories and storytelling) as well as distance (in positioning the stories within the text).

This strategy seems to have been more appealing in the late 1980 s and 1990 s, when attention shifted from representation of the war to representation of remembrance of the war. The most important example here is Claude Lanzmann's documentary film, Shoah (1985). Since Lanzmann's documentary, the potential power of the witness has been acknowledged and further elaborated. Being the proper practice of the working of memory, witnessing as a process became more important than the testimony itself. Many films use witnesses as an important (sometimes as the most important) rhetorical argument in the narrative. Oral history is used to compensate for the lack of archival material, at the same time as it questions and re-evaluates remembrance as an unstable factor. The use of oral history emphasizes the contribution of witnesses to our understanding of history. The filmmaker has become a witness himself to the making of the testimony. The preliminary end of this development can be seen in Steven Spielberg's project Survivors of the Shoah, Visual History Foundation (2004): a worldwide vast collection of testimonies - however, it is one without a cinematographic context since there is no filmmaker to structure them in one way or another. The testimonies have been digitalized for all eternity, so that users in the third and fourth generations and beyond 
can go back to the original stories. Films using testimonies are about memory, the process of remembering, how differently people see things, how the human mind works. The second and third examples illustrate this more explicitly.

The film Settela: Face from the Past (Cherry Duijns, 1994), discusses the remembrance of the Shoah. This documentary traces back into history and present-day memory by studying the impact of seven seconds of archival footage of a transportation that became world famous. These seven seconds have been recycled again and again, ever since Alain Resnais used them so manifestly in Night and Fog. The short film clip became a symbol of the masses of deported Jews, and a worldwide symbol of the Shoah.

The film clip shows the moving image, in close-up, of a girl with a white headscarf in the doorway of a train due to depart from Westerbork. The close-up of the girl is edited between images of SS officers walking along the train wagons on the platform, while dogs watch. The clip is part of a 70-minute long Westerbork camp film made under the orders of Obersturmfiuhrer Gemeker in spring 194.4 by the photographer Rudolph Breslauer, himself an inmate. Breslauer, a Jew, had fled from Germany and was asked to film daily life in the camp. Later in 1944 he was transported to Auschwitz and murdered. In Cherry Duijns' documentary film, it is suggested that Breslau shot the pictures of the girl in the doorway intentionally, as a frightful indictment to be shown to the world, and edited them between 'normal' images of departure routines in such a way that the Obersturmfuhrer would not notice: a singular moment, rendered indelible. The identity of the girl was not known. Her image represented the objectification of the Shoah, erasing the individual. It became an image to which meanings were added without knowledge of the origin of the source.

In the film, Duijns follows the research of journalist Aad Wagenaar as he sought the identity of the girl, filename 'Esther'; their aim is to question the origin of the image and to historicize it. Through close analysis of the signs, letters and numbers on the wagon truck as shown in the footage film, the trace leads to the transport of 19 May 1944, a Gypsy transport, and further to a few Gypsy survivors, one of whom recognizes and reveals the identity of the girl: a Gypsy girl named Anne Maria Steinbach, 'Settela' by her Gypsy name.

Wagenaar personalized the abstract representation, putting the sevensecond footage into historical perspective. Afterwards, he faced strong culturally and historically-defined reactions both from the Gypsy and Jewish communities. The Jewish community felt as if they had been robbed of a symbol, as they had identified themselves with the image. All over the world, the identity of the girl had been read as Jewish, an imaginary projection of the victims of the Shoah. The introvert Gypsy community did not want to become public since, as the film puts it, 'Memories are kept in the heart. The dead must not be discussed in public.' Although 
it welcomed the attention given to its suffering in the Shoah, it feared a repetition of history, as one of the main witnesses says in the film.

Wagenaar discovered only in 1993 that the image of the girl indeed was anonymous (and not only kept anonymous), and began his search for her identity. Another 'Unknown Soldier' was given a name, and the name-giving helped to generate more attention for individual voices in memorial services that take place in Westerbork as a memorial centre. Duijns uses the actual Westerbork memorial place in his film as a site of memory, next to archival material and oral history, put in the narrative form of a quest, discussing historical truth as well as the truth of memory. As a filmmaker, he constantly articulates his presence as the "constructor" of this part of reality, while at the same time arguing convincingly for the identity of the girl as a Gypsy. The film draws attention to the tensions that arise when statements contradict one another, revealing the act of remembering. This is the work of the film text, not the viewpoint of one of the witnesses, and here the film stays away from realist discourse. It takes up a 'middle voice', objective in its presentation of archival material and oral history, however contradictory that may sound, subjective in its poetic commentary, written and spoken by the filmmaker himself. By looking for the relationship between film and memory, Duijns seeks a way to be in dialogue with the past, constituting a meaningful relationship with it. Thus Settela's face, still an indictment, has become the face of the deported. The research and the film made room for more voices to be heard, for more individual memories, in which the individual Settela lives on. Wagenaar's search and Duijns' film led to the first Gypsy memorial service in Westerbork in 1994, which was broadcast live on television.

The last film to be discussed deals with Memorial Day, when Anne Frank, Settela, and all of the fallen since the beginning of the Second World War, are remembered. A unique moment during this annual ritual is the two-minute silence just before $8 \mathrm{pm}$. Memorial Day, even more so its television broadcast, can be regarded as a ritual in the sense that it potentially produces an experience of social cohesion at prefixed moments. Its live broadcast on national television channels is what Dayan and Katz (1995) call a 'coronation', a ceremonial broadcast which transmits the idea of community, focusing on national identity. Not only is it perceived collectively (people who do not participate in the actual commemoration watch it on TV), but is intended as a celebration of the collective. Through the act of memory, it recalls the continuity of a society. In 2 Minutes of Silence, Please (Heddy Honigmann, 1998), different voices are given room and screen time to articulate different discourses of memory. The speaking position is expressed exclusively through individual voices, brought together by the filmmaker in a narrative.

Honigmann asks several people on the morning and afternoon of Memorial Day what this day means to them. In the film she visits a Jewish filmmaker, a writer, a coffee shop owner on Dam Square, Amsterdam (where 
the official commemoration takes place), the daughter of a Dutch Nazi, a Hungarian refugee, a young schoolgirl, a woman who suffered in the Japanese camps, a man who saw his Jewish schoolmate taken away, never to return, and an old lady who served in Jewish homes. On the evening of 4 May, various camera crews follow these people simultaneously during their visit to the memorial services at several places in the country, or just at home, filming them during the two minutes' silence.

In answering the filmmaker's questions in the film (although Honigmann herself is not seen), they reflect on the relationship between memory and history from a personal point of view. By slight references to 'we', 'us' and 'they', they provide at the same time the broader social and historical context from which they speak. This context, for example communist oppression in Hungary, ties personal memories to the construction of a more collective memory, which in this film becomes concrete in that all these different people, with their different historical experiences, participate in an official act of remembrance, the commemoration service on Memorial Day. The film thus constructs and discusses memory on a personal level, and at the same time in its narrative it builds the framework for signifying the official national way of commemorating the Second World War and the Shoah. It is a film about how memories circulate and relate to concepts of national identity articulated through national commemoration scripts, such as Memorial Day at Dam Square. In the way that personal and public memory are integrated in this documentary, this film in fact both expresses and prompts a pluralist culture of memory. As such, it explores how individual experiences are projected onto institutionalized and public ways of commemorating, such as Memorial Day. It represents a clear example of contextualized images that converge in one specific moment (two minutes of silence) by adding very individual meanings.

In searching for remembrance of the Second World War and the Shoah, this documentary is both a source and representational form. Honigmann's film is a concrete illustration of how new forms of representation, which express different relationships with the Shoah, have appeared, how personal memory deepens public memory, and vice versa. In representing a variety of voices and thus of discourses of memory, it articulates that there are different answers to the question: 'Whose war is represented?' There does not seem to be a speaking part for the nation as a whole other than the collectively experienced national Memorial Day commemorative practice. But as long as the ritual is kept alive (it should be), personal memories will have a common focal point, one which offers room for individuals to mourn, to honour, to remember, to commemorate their own deaths, keeping together the self and the collective, ready to enter a new age.

What we have discussed here is how filmmakers in the 1980s and 1990s began to recontextualize images of the Shoah by taking new representational approaches such as modernist narrative strategies. The use of these new cinematic devices offered filmmakers the opportunity to take new paths 
of historical representation. They contest the fixed meanings that history had produced so far, which had been given form in documentary images. Following modernist storytelling strategies, documentary film is able to deconstruct the fixed meaning of images in order to make room for a diversity of stories, individual stories which at the same time count for many forms of memory. The documentary image has become available again for historical representation.

\section{Notes}

1. Marcel Ophüls, son of Max, who critically researched French Second World War history in, for example, The Sorrow and the Pity (1972) about the myth of the French resistance, and who made Hotel Terminus: Klaus Barbie, His Life and Times (1988), about the 'Butcher of Lyon'. Ophüls is indebted to the tradition of cinéma vérité in the way that he confronts existing opinions about history with his filmic research.

2. They prefer the term 'collective remembrance' (Winter and Sivan, 1999: 9).

3. Panel discussion, 'Historical Representation and the Holocaust', Visible Evidence Conference in San Francisco, CA, 14 August 1998 (see also Hirsch, 2004).

4. These limits are extensively discussed in Friedländer (1990). For extensive discussions on the relationship between history and film, see Rosenstone (1995).

5. Hirsch (2004) fully explores the representation of traumatic experiences in terms of post-traumatic cinema.

6. Film historian Ilan Avisar suggested that all the techniques available for the representation of the Holocaust can be linked to stages in documentary film history. Panel discussion, 'Historical Representation and the Holocaust', Visible Evidence Conference, San Francisco, CA, 14 August 1998.

7. See Vos (1995) for television programmes on the German occupation of The Netherlands, produced in the $1960 \mathrm{~s}, 1970$ s and $1980 \mathrm{~s}$.

8. To quote Rosenstone, 'somewhere between the objective voice of scholarship and the subjective voice of fiction and poetry' (1996: 216).

\section{References}

Burgoyne, R. (1996) 'Modernism and the Narrative of Nation in JFK', in V. Sobchack (ed.) The Persistence of History. Cinema, Television and the Modern Event, pp. 113-25. London: Routledge.

Dayan, D. and E. Katz (1995) 'Political Ceremony and Instant History', in A. Smith (ed.) Television. An International History, pp. 169-88. Oxford: Oxford University Press.

Friedländer, S. (1990) 'Some Reflections on the Historicization of National Socialism', in P. Baldwin (ed.) Reworking the Past. Hitler, Holocaust and the Historians' Debate, pp. 88-101. Boston, MA: Beacon Press.

Friedländer, S. (1993) 'Trauma, Memory, and Transference', in G. Hartman (ed.) Holocaust Remembrance. The Shapes of Memory, pp. 104-16. Oxford: Blackwell.

Friedländer, S. (1994) Memory, History and the Extermination of the Jews in Europe. Bloomington: Indiana University Press. 
Hirsch, J. (2004) Afterimage: Film, Trauma and the Holocaust. Philadelphia, PA: Temple University Press.

Kaes A. (1989) From Hitler to Heimat. Cambridge, MA: Harvard University Press.

Nichols, B. (1991) Representing Reality. Issues and Concepts in Documentary. Bloomington: Indiana University Press.

Rosenstone, R. (1995) Revisioning History: Film and the Construction of a New Past. Princeton, NJ: Princeton University Press.

Rosenstone, R. (1996) 'The Future of the Past: Film and the Beginning of Postmodern History', in V. Sobchack (ed.) The Persistence of History. Cinema, Television and the Modern Event, pp. 201-18. London: Routledge.

Staiger, J. (1996) Cinematic Shots: The Narration of Violence, in V. Sobchack (ed.) The Persistence of History. Cinema, Television and the Modern Event, pp. 39-54. London: Routledge.

Vos, C. (1995) Televisie en Bezetting [Television and Occupation]. Hilversum: Verloren.

White, H. (1996) 'The Modernist Event', in V. Sobchack (ed.) The Persistence of History. Cinema, Television and the Modern Event, pp. 17-38. London: Routledge.

Winston, B. (1995) Claiming the Real. The Documentary Film Revisited. London: British Film Institute.

Winter, J. and E. Sivan (1999) 'Setting the Framework', in J. Winter and E. Sivan (eds) War and Remembrance in the Twentieth Century, pp. 6-39. Cambridge: Cambridge University Press.

Young, J. (1988) Writing and Rewriting the Holocaust. Narrative and the Consequences of Interpretation. Bloomington: Indiana University Press.

\section{Biographical note}

Sonja de Leeuw is Professor of Dutch Television Culture in an International Context, University of Utrecht. She is the author of Television Drama, Stage for Identity: A Study on the Relationship between Identity of Broadcasting Companies and Dutch Television Drama 1969-1988 (Cramwinckel, 1995; in Dutch). She publishes on television culture, historical representation, media and diasporas, and media and youth culture. ADDRESs: Film and TV Studies, University of Utrecht, Kromme Nieuwegracht 29, 3512 HD Utrecht, The Netherlands. [email: sonja.deleeuw@let.uu.nl] 